\title{
Bacillary Peliosis
}

National Cancer Institute

\section{Source}

National Cancer Institute. Bacillary Peliosis. NCI Thesaurus. Code C128340.

An infection that is caused by Bartonella henselae, which occurs primarily in immunocompromised persons; it is characterized by blood-filled cysts in the liver and spleen. 